\title{
Government Publishing in Wartime
}

A statement submitted to the United States government by the American Library Association.

$\mathrm{T}$ HIS MEMORANDUM presents observations and suggestions on government publishing in wartime based in part on the needs of educators, students, scholars, professional organizations, colleges, universities, schools, and libraries, but primarily on the usefulness of such persons and agencies to the government in getting the right publication to the right person at the right time.

It recognizes the wartime necessity for economical use of funds, manpower, and machinery and also the importance of keeping people informed. It discusses briefly the different kinds of publications issued by the government and makes specific suggestions to increase the efficiency of publishing and distribution procedures.

In its preparation the A.L.A. has had advice from representatives of the American Council of Learned Societies, $\mathrm{National}$ Research Council, Social Science Research Council, American Council on Education, and other scholars; from several government officials and employees; and from many general and special librarians. However, the American Library Association is alone responsible for the statement as presented.

\section{INTRODUCTION}

The wartime increase in the powers and activities of the executive branch of the government, the demand for speed in decision and action, the need for economy, the need for unity, the temporary curtailment of personal privileges, the eagerness of people to know what is going on and what they can do to help-all these factors increase the importance and add to the difficulties of government publishing in wartime.

The channels of communication between the government and the people must be kept open, possibly expanded. Speed and economy may be sought through improved administrative and editorial procedures, new technological advances in printing, and coordinated distribution.

\section{THE GOVERNMENT AS PUBLISHER}

The government's responsibilities as publisher appear to fall rather naturally into the following categories:

A. Administrative, legislative, and judicial reporting.

B. Administrative rules, regulations, and announcements.

c. Information and education.

D. Research.

These categories are not always mutually exclusive. An administrative report, for example, is often useful in education or research but it would be classified as a report if reporting were the primary intention of the issuing agency. The classification is intended merely to lend clarity to the following discussion of the different kinds of government publications 
and to assist in defining the kinds of documents to be distributed by the several methods described in the third section.

Publication is defined by Webster's New International Dictionary as "the issuing to the public of copies, now usually printed or similarly produced copies, of a book, engraving, or the like." When we speak of publications in this memorandum we mean printed and "processed" materials which either have been "issued to the public" or whose usefulness would be increased if "issued to the public."

A. Administrative, Legislative, and Judicial Reporting

It is a necessary function of administrative officials in a democracy to report periodically to the President or to the Congress and to the people on what they have done; and of legislative and judicial authorities to publish their reports, documents, proceedings, hearings, laws, and court decisions. We believe that such reporting is even more essential in wartime than in peace because of the great expansion of government activities and the greater urgency that people shall have information enabling them to act wisely and with confidence in their elected and appointed officials.

\section{Examples}

Annual Report of the Civil Service Commission.

Annual Report of the Secretary of the Navy. The Congressional Record.

Reports and Documents of the House and Senate.

Hearings of the House and Senate Committees.

Official Reports of the Supreme Court.

\section{Recommendations}

I. We recommend that all government agencies be required to report periodically.

2. We suggest that any necessary curtailment for purposes of economy be effected through reduction in length (where that is possible without affecting substance), production in more economical form, and elimination of wasteful distribution; but not in discontinuing the reports or so limiting their editions as to prevent distribution to people who will make good use of them.

3. We urge that reports which, because of their confidential nature, cannot be given out now except to a restricted group of government officials, be held for general release after the war.

B. Administrative Rules, Regulations, and Announcements

These documents are produced in the normal everyday job of administration by the various agencies for the guidance of their own personnel, the information of other government agencies, and the instruction of particular groups of people, such as the leaders in one industry. They are the tools of the trade, the necessary implementation of administrative decisions and orders. These administrative documents are growing in number and importance with the increase in the administrative and quasi-legislative powers of the executive branch of the government.

\section{Examples}

The Federal Register.

Regulations of the Office of War Information.

Service and Regulatory Announcements of the Bureau of Animal Industry.

Rules of the Supreme Court.

Calendars of the House and Senate.

Directives of the War Manpower Commission.

\section{Recommendation}

4. In our opinion all administrative rules, regulations, and announcements (except those which are intended only for internal administration) should be made available 
not only to officials and to the special groups concerned but also to the special and general libraries which serve those groups. It should be remembered too that these publications are a part of the record of the government's wartime activities and should be preserved in appropriate libraries and archives for the social scientist.

\section{Information and Education}

The Office of War Information was created in recognition of the fact that people need many kinds of information if they are to participate helpfully in war activities and if they are to have intelligent opinions on the problems and issues which confront them as citizens. They need accurate news of events at home and on foreign fronts; information about the various government agencies and their several responsibilities; accurate and authoritative information on the techniques of daily living and working under war conditions; and assistance in developing a sound understanding of the wartime policies of the government, the civilian sacrifices those policies make necessary, and the postwar problems created by the war.

\section{Examples}

Press Releases of the Office of War Information.

The United States Government Manual.

Vegetable Varieties of Soybeans.

Pre-Aviation Cadet Training in High Schools.

The Unconquered People.

Divide and Conquer.

\section{Recommendations}

5. The need for informational and educational publications on such subjects as food, nutrition, health, fuel, conservation, care of children, civilian defense, technical training, and employment is even more urgent in wartime than in peace. Publications in these and other well-established fields of government activity should be continued as essen- tially related to the war effort. Some now issued in very limited editions for a particular group should be reissued in large editions for a wider audience.

6. Readable publications designed to develop a fundamental knowledge of the meaning of democracy, the policies directing our war effort, the issues involved in those policies, the peace objectives of the United Nations, and the problems of postwar planning should be produced in attractive form and widely distributed to individuals, libraries, and other agencies.

7. Some news and press releases, in addition to their normal distribution, should be sent to selected research and reference libraries which need them for serious students and research workers.

\section{Research}

The important research publications of the United States government are of three kinds: (I) Publications reporting the results of government research; (2) Publications presenting statistical and other information which is used as the basis for both government and private research; and (3) Indexes and bibliographies necessary to the effective use of research publications. These publications are important to the well-being of the American people; many are of direct value in the prosecution of the war.

\section{Examples}

Journal of Research. (Department of Agriculture and Bureau of Standards)

Determining of Characteristics of Tapered Wings. (National Advisory Committee for Aeronautics)

Research: A National Resource. (National Resources Planning Board)

Financial Statistics of Cities. (Bureau of the Census)

Index-Catalogue of Medical and Veterinary Zoology. (Bureau of Animal Industry)

Index-Catalogue. (Army Medical Library)

Statistics of State School Systems. (Office of Education) 


\section{Recommendations}

8. We believe that the publication of research should be recognized as an integral part of the research process. It seems patently unwise and uneconomical to spend millions for research which cannot reach its full and ultimate ends without publication. This is especially true of government research which, even though its immediate purpose might be achieved within a particular bureau without publication, is useful and important to the conduct of other similar research by other departments of the government and by private agencies.

9. In a war such as this we believe that a liberal interpretation of what will aid warrelated research must be made. For example, the Index-Catalogue of Medical and Veterinary Zoology is an indispensable aid to research workers in tropical medicine, veterinary science, and conservation. As the first two of these fields are definitely related to the war, the discontinuation of this publication may hamper the war effort.

Io. In issuing and distributing research publications during the war, we urge that the needs of scientists and institutions engaged in war-related research all over the country be remembered as well as the needs of those at work in Washington.

II. We believe that such curtailment as is necessary, either for economy or to avoid giving aid to the enemy, should be through delaying publication and temporarily limiting distribution and not by measures which will permanently jeopardize the work of scholars and scientists who need such materials.

12. As all government records and publications are useful for research, they should be properly preserved and distributed for such use.

\section{E. In General.}

As with research publications, it is our opinion that government publishing in general should not be considered as a separate activity but rather as a necessary arm of nearly every government agency. It is perhaps worth noting that govern- ment publishing, contrary to some opinion, has not expanded as much as other government functions. Expenditures for printing are about five times what they were forty years ago, whereas the operating expenses of the government as a whole have increased nineteenfold. In 1900 government operating expenditures devoted to printing amounted to nearly I per cent; by 1940 this proportion had dropped to less than one fourth of I per cent. This is not to argue against economies which can result from better management, but these facts do indicate that the current volume of government publishing is by no means the domineering colossus so frequently suggested.

It is to be noted also that in recent decades the level of education has risen, interest in government activities has increased, and the agencies for disseminating information have become more numerous. There is greater opportunity now than ever before for the government to make good use of its publications.

\section{Recommendations}

13. The codification of many documents into a relatively few numbered series within each department or issuing agency and the elimination of most unnumbered publications would be in the interest of economy and efficient handling. This practice has long been successfully followed by the Department of Agriculture and the Office of Education.

14. We believe that economies in printing and some simplification in handling would also result from the wide use of existing serial publications for releasing reports, regulations, information, and results of research, in preference to creating new publications and new series. All administrative orders and regulations which have effect outside the issuing agency, for example, might well be published in The Federal Register. 


\section{DISTRIBUTION}

We recognize that the problem of distributing government publications is enormously complex. Contributing to this complexity are such factors as the large number of issuing offices, the inequality of printing funds available to the several agencies, the many kinds of printed and "processed" documents, the fairly indiscriminate mixture of sales and free distribution, the somewhat unsystematic distribution by congressmen, and a very imperfect depository library system.

We are not unmindful of the necessity and economy of conveying information through newspapers, magazines, radio, and motion pictures; or of the desirability of sending reports, regulations, and other selected publications to national, state, and local officials; but as such methods and such distribution are without the province of this memorandum, we have not attempted to deal extensively with these problems.

The observations and suggestions which follow are based in part on the needs of educators, students, scholars, professional organizations, colleges, universities, schools, and libraries, but primarily on the usefulness of such persons and agencies to the government in getting the right publication to the right person at the right time.

\section{Recommendations}

15. We endorse the announced purpose of O.W.I. to bring about some organization of control over general "request" mailing lists. Such control, we think, should result in expansion where that is needed, as well as in curtailment, for it is certainly more important to the war effort to get publications into the hands of people who will make good use of them than it is to avoid a small percentage of ineffective distribution.

I6. In preparing and revising mailing lists, particular attention should be paid to the thousands of educators, students, and scholars, and especially to the schools, colleges, universities, libraries, and organizations with which they are associated. These individuals and agencies are always available for use in the dissemination of information, and through them the government can reach a very large portion of the public. In planning distribution to these groups the government agencies which know most about their needs, activities, and capabilities should be called upon for advice.

I7. Because of the importance of getting government publications to the American people at this time, no existing channels of distribution should be closed unless better ones are opened up.

I8. The purpose of free distribution should be, not to serve the purely personal interests of the recipient, but to advance the national welfare.

\section{A. Depository Libraries}

Five hundred and forty-four libraries have been designated by congressmen as depositories of United States government publications. One hundred and twentythree of these are, by choice, "all" depositories and receive all printed documents available for distribution to depository libraries by the Superintendent of Documents. The other $42 \mathrm{I}$ libraries receive only those series of printed documents in which they have indicated an interest.

\section{Recommendation}

19. We think the depository library system, in spite of its obvious imperfections, should be continued until the long-needed field survey of depository libraries can be made, possibly after the war. (Note also recommendation $2 \mathrm{I}$.)

\section{B. Libraries in General}

We believe that the government should make maximum use of libraries as agencies for getting war-related publications to the 
people who are to use them. The discontinuation of general mailing lists and the curtailment of special mailing lists may handicap the war effort if individuals and organizations dropped from the lists are not otherwise able to have access to the publications they need. Individual requests for free and sale copies of particular documents will in part meet this need. We think that a large part of the need should be met by libraries.

There are in the United States some:

6200 public libraries (city, county, and state)

I 700 college and university libraries (including teachers colleges, technical schools, and junior colleges)

6000 to 7500 school libraries (depending on how small a collection of books is called a library)

I 500 to 2000 special libraries (including business, banking, technical, law, medicine, legislative reference, etc.)

It should also be emphasized that many public, university, and school libraries have several branches. One large public library has 65 ; a large university library has 80; one large school system has 127. (It is also necessary to record the unfortunate fact that many communities do not have adequate libraries of any kind.)

Many libraries are staffed by librarians skilled in making printed matter serve the needs of their clientele and eager to advance the nation's war effort. They can and do bring publications to the attention of many millions of people, individually and in groups, and they try to make a practice of having each publication on hand when it is wanted, immediately on publication or any time thereafter. Many of the people who use libraries are employed in war industries or engaged in other war activities; they need access to government publications.

\section{Recommendations}

20. We endorse O.W.I. Regulation 5, Section 7 , providing that library mailing lists be continued and also that libraries be asked to justify the retention of their names on "request" lists. Libraries would prefer, for reasons of economy, to justify their place on mailing lists to one agency for groups of publications rather than to each issuing agency for particular publications. Such justification should also allow requests for additional publications, printed and "processed," not now being received.

2I. We believe that arrangements should be made to supply "all" depository libraries' or important reference and research libraries selected on a regional basis, with complete files of both printed and "processed" publications for United States government officials now widely distributed over the country and for students and scientists in general. If some of these publications are temporarily restricted, they should be held for distribution to these libraries after the war.

22. Approximately seven hundred large library systems, public (state, county, and city), university, and school, should receive all war-related publications, including multiple copies for branches and departments as needed.

23. Five to ten thousand additional public, college, school, and special libraries, in accordance with their need and with the availability of copies, should receive all warrelated publications issued by government agencies for the information and education of the general public. These publications should be pre-selected and distributed as soon after publication as possible.

24. Special libraries devoted to engineering, medicine, law, art, technology, business, banking, and other special subjects, should promptly receive documents related to their special interests and needs. If some documents in these fields must be temporarily restricted, they should be held for these libraries until after the war.

25. Some of the information and education publications, particularly those concerned with the developing of an under-

\footnotetext{
${ }^{1}$ See Section A, page 104.
} 
standing of government policy or with personal participation in war activities, which the government desires to have reach practically everybody in the country, should be sent to selected libraries in quantity for distribution to the public.

\section{Sales}

The Superintendent of Documents in the fiscal year 1940-4I sold twentyfour million documents for a total of $\$ 1,300,000$. Large as these figures are, we believe they can be greatly increased and that by increasing sales, much free distribution of the shotgun variety can be eliminated. We are convinced that many individuals and institutions would willingly buy government publications if buying were made easy.

\section{Recommendations}

26. There should be established a sales stock of all or most emergency publications as well as regular publications, "processed" as well as printed.

27. An appropriate government agency should be authorized to operate retail stores in several regional centers for over-thecounter and mail-order sales of documents and to promote sales through appropriate local agencies, such as bookstores, department stores, and libraries.

28. Mail-ordering should be facilitated by enabling purchasers in the easiest possible manner to order through their local post office.

\section{Foreign Distribution}

In spite of the earnest endeavors of many federal agencies, the government's distribution of documents to foreign countries is inadequate and, as a whole, unplanned. Division of responsibility and authority appears to be the cause of much difficulty in getting needed documents to officials, libraries, and scholars of foreign countries and to American officials stationed abroad.

\section{Recommendation}

29. It is urged that a program of distribution to other countries and to our own representatives abroad, commensurate with the needs of the situation in wartime, be made and inaugurated with all possible speed and that stocks of restricted publications be reserved for foreign distribution after the war.

\section{LISTING AND CATALOGING}

No amount of intelligent advance care with mailing lists will put all documents in sufficient quantities into the hands of all the people and institutions able to make appropriate use of them. Legitimate requests for free copies as well as orders for sale copies would be greatly facilitated by better lists, more promptly issued, more widely distributed. The existing cataloging, as exemplified by the Price Lists, The Weekly List, and The Monthly Catalog, all issued by the Superintendent of Documents, have long been inadequate.

The Weekly List, which is largely an advertising device, does not meet the present urgent need for a comprehensive current list of government publications. The Monthly Catalog no longer records all documents printed at the Government Printing Office, never has included publications issued by the field agencies and offices, and, although an attempt was made in 1936 to incorporate in it the important "processed" documents, has never even approximated complete coverage. The Service Division, Bureau of Public Inquiries, Office of War Information, and the Office of Education have both attempted selective lists of national

(Continued on page IIg) 
more withdrawals of books and more modifications of arrangements to suit a flexible curriculum. The clerical functions will probably not require special library training.

One of the great sources of support for libraries in the future will come from alumni, organized into such groups as the Friends of the Knox College Library, which Edward Caldwell, of New York City, has developed in the past ten years into a vital part of our whole library structure, spiritually and financially.

\section{Relations with Administration}

Perhaps I should say a last word about future relations of the college administration to the library. It is safe to say the trustees and executive officers have always been concerned-the history of Knox shows that back in 1853 , when the total educational budget of the college was only $\$ 4350$, the trustees appropriated $\$ 500$ for library expansion. The library of the future has a right to expect continued support from the administration, but it must be remembered that every department must be judged by the results it produces, and if the library uses its plant carelessly, fails to adjust itself to the changing curriculum, discourages faculty members, or hampers the educational development of the students, it is on the spot.

But today, in 1942 , the library on the average college campus is not on the spotit is rather on the threshold of great new opportunities, not for physical expansion, but for important educational service.

\section{Government Publishing in Wartime}

\section{(Continued from page 106)}

defense and war publications. However, comprehensive recording as well as selective listing is needed.

Adequate listing is essential not only to efficient distribution but also to the current and future handling and use of documents by librarians, teachers, students, and research workers.

\section{Recommendations}

30. We believe that some agency of the government should issue weekly or biweekly lists of current printed and "processed" publications. This might be accomplished as a new service or might be incorporated in some existing weekly or biweekly government periodical. Provision should also be made for quarterly or semi- annual subject indexes to these lists.

31. We recommend that, pending the inauguration of periodic listing of all government publications, each department or independent agency be encouraged to issue lists of all of its own publications.

32. All publications, including those which are restricted or confidential, should be included in such lists if not contrary to the public interest.

If government publishing is, as we believe, a tool for use in achieving important national objectives, it is worth the effort now being made to develop a positive policy and program for the employment of that tool for the best possible results. 